\title{
Application of Dermatoglyphic Traits for Diagnosis of Diabetic Type 1 Patients
}

\author{
Hossein Rezaei Nezhad, Nasser Mahdavi Shah
}

\begin{abstract}
Nowadays study of dermatoglyphics has a great importance in judicial and criminal researches. At present, study of dermatoglyphics that is related to some genetic diseases has an immence application. Relation of dermatoglyphics characteristics with some of diseases like down's syndrome, Alzheimer's disease, multiple sclerosis, schizophrenia has been studied . Genetic factors are important in the causation of both types of diabetes. Count of palm dermal ridges are very important in determining quantitaive fingerprint characteristics. Also dermal ridges in fingers have different shapes, similar loop, arch , whorl which are too important in qualitative characteristics. In this project we selected 30 patients and impregnated their palms with ink and pressed on papers and their results were compared with control group. The results were analysed by statistical tests. i.e. t-test and chi-square. Results Indicated that a-b count in male and female patients has decreased comparatively to control group, but the reduction is not significant. From the viewpoint of the shape of fingerprint, loop and whorl shapes are heterogeneous and their number differ significantly comparative to control group ( $p=$ 0.001. $p=0.004$.) It seems that dermatoglyphics could be a suitable method for genetic studies and diabetes type 1 .
\end{abstract} Iran.

Index Terms-Dermatoglyphics, diabetes , genetic diseases,

\section{INTRODUCTION}

Investigators have carried out scientific projects concerning to dermatoglyphics. These researches show that there is a relation between dermatoglyphics and some diseases, similar schizophrenia , Down's syndrome , Alzeihmer , Mutiple Sclerosis , congenital spinal cord anomalies. $(1,2,3,4)$ In dermatoglyphics studies, we pay attention to quantitative and qualitative characteristics. Dermal ridges form some shapes (whorl, loop, arch) on fingers (Fig.1). a-b,b-c,c-d lines and atd angles are another indexes that are considered as another characteristics (Fig.2) Diabetes is a global disease that is growing, therefore investigators are looking for new methods for its diagnosis and treatment .

In this research we are going to specify the dermatoglyphics characteristics of diabetic patients, therefore possibly we will able to diagnose diabetes by using

Hossein Rezaei Nezhad is with Islamic Azad University of Shirvan , Shirvan , Khorasan , Iran

Nasser Mahdavi Shah is with Biology Department , University of Mashhad, Mashhad, Iran

Corresponding author . tel : +989153171476, fax : + 985854224117 email: saman59816@yahoo.com of these characteristics.

Dermal characteristics are stable in fetus and after birth till end of life and environmental alterations could not change them.

Nowadays a remarkable understanding of dermatoglyphics has been gained and analysis of dermal ridges could be used in diagnosis of some diseases.

Sine it was found that patients with choromomal anomalies have uncommon fingerprints, this science was focused on genetic diseases and made progressed enormously . (5,6).

It is noticeable that studing only a characteristic is not enough for diagnosis but sum of characteristics is helpful.

Use of analytical methods and computer in analysis of dermatoglyphics has increased utilization of dermatoglyphics in medicine $(7,5,6)$

However , identity and criminology first spring to mind concerning to dermatoglyphics, but it should be noticed that it has an immence usage in medicine. (5)

\section{METHODOLOGY AND MATERIALS}

30 patients were selected as test group in central province, also a 30 control group was considered .

Mean age of patients and control group was $22 \pm 11$ and $38 \pm 8$ respectively.

Some aspects of patients like background of congenital disease, dyspnea, hypertension, cardiac diseases and personal information were recorded.

The age of control group was over 30 years old. For recording of fingerprint we use of print ink. Some ink is spread evenly on a glassy plate, so we will have a thin layer of ink. Fingers are impregnated with ink and are pressed on A4 paper. Plus sole of hands are impregnated and are placed on a paper of sheet that is located on a cylinder and is pushed forward slowly.

We could find triradioses (a,b,c,d) at the base of each finger on paper. After determining of these triradioses, we joint them together . Therefore we have a-b,b-c,c-d lines. We count the ridges on a-b line by lens or stereomicroscope .

We compare a-b ridge count and the shape of fingerprint on tip of fingers concerning to control and test groups by profiting of t-test and chi-square.

\section{RESULTS}

In examined cases $42 \%$ of patients were man and $58 \%$ of them were women. Dermatoglyphic of palms and measuring of a-b ridge was examined in both men and women separately. The result of a-b ridge count in all the people (male and female) in both control group and test group in table 1 , shows that the mean of ridge count is increased in the 
group of diabetes men rather than control group.

Table 2 shows the mean of $(\mathrm{X} \pm \mathrm{SD})$ of $\mathrm{a}-\mathrm{b}$ ridge in both men and female and also in both test group and control group. It is observed that there is no meaningful difference among the mean of a-b ridge.

Table 3 illustrates the number of fingerprints in whorls, Loops and Arch in both test group and control group .Test and odds- ratio test also show that the concept of whorls distribution in test group is 1.74 time of control group. This ratio is meaningful in 5\% level (significant interval is 95\% for odd- ratio 2.02 and 1.025). Loops distribution in test group is 0.05 time of control group. This ratio is meaningful in 0.05 level. (significant interval is $95 \%$ for odds-ratio 0.77 and 0.4). Arch distribution in both test group and control group is homogeneous. The amount of odds- ratio which is not meaningful, is 0.84 (significant interval is $95 \%$ for odds-ratio 1.29 and $54 \%$ ).

\begin{tabular}{|c|c|c|c|c|c|}
\hline \multirow{3}{*}{$\begin{array}{l}\text { Test } \\
\text { group }\end{array}$} & $\begin{array}{l}\text { Hand } \\
\text { type } \\
\text { Sex }\end{array}$ & $\begin{array}{l}\text { Right } \\
\text { hand }\end{array}$ & $\begin{array}{l}\text { Left } \\
\text { hand }\end{array}$ & $\begin{array}{l}\text { Right } \\
\text { and left } \\
\text { hands }\end{array}$ & $\begin{array}{l}\mathrm{a}-\mathrm{b} \\
\text { ridge } \\
\text { mean }\end{array}$ \\
\hline & Men & 38.07 & 37.4 & 75.31 & \multirow{2}{*}{72.59} \\
\hline & women & 34.25 & 25.54 & 68.9 & \\
\hline \multirow[t]{3}{*}{$\begin{array}{l}\text { Control } \\
\text { group }\end{array}$} & $\begin{array}{l}\text { Hand } \\
\text { type } \\
\text { Sex }\end{array}$ & $\begin{array}{l}\text { Right } \\
\text { hand }\end{array}$ & $\begin{array}{l}\text { Left } \\
\text { hand }\end{array}$ & $\begin{array}{l}\text { Right } \\
\text { and left } \\
\text { hands }\end{array}$ & \multirow[t]{3}{*}{$\begin{array}{l}\mathrm{a}-\mathrm{b} \\
\text { ridge } \\
\text { mean }\end{array}$} \\
\hline & Men & 36.2 & 35.6 & 70.89 & \\
\hline & women & 33.64 & 35.29 & 68.45 & \\
\hline
\end{tabular}

TABLE2: THE COMPARISON OF DERMATOGLYPHICS QUANTITATIVE PARAMETERS IN DIABETES PATIENTS (TYPE I) OF CONTROL GROUP.

\begin{tabular}{|l|l|l|l|l|}
\hline $\begin{array}{l}\text { a-b ridge } \\
\text { in sex }\end{array}$ & $\begin{array}{l}\text { Hand } \\
\text { type }\end{array}$ & Test group & $\begin{array}{l}\text { Control } \\
\text { group }\end{array}$ & P-V \\
\hline Female & right & $34.25 \pm 4.07$ & $33.64 \pm 3.03$ & 0.610 \\
\cline { 2 - 5 } & left & $35.55 \pm 3.86$ & $35.29 \pm 5.01$ & 0.888 \\
\hline \multirow{2}{*}{ Male } & right & $38.07 \pm 5.48$ & $36.20 \pm 4.78$ & 0.395 \\
\cline { 2 - 5 } & left & $37.4 \pm 5.34$ & $35.6 \pm 5 / 36$ & 0.418 \\
\hline \multirow{2}{*}{ total } & right & $36.31 \pm 5.17$ & $34.71 \pm 39.7$ & 0.229 \\
\cline { 2 - 5 } & left & $36.62 \pm 4.78$ & $35.42 \pm 5.05$ & 0.392 \\
\hline
\end{tabular}

TABLE1: THE COMPARISON OF A-B RIDGE COUNT MEAN IN BOTH TEST GROUP AND CONTROL GROUP.

TABLE3: FREQUENCY DISTRIBUTION OF FINGERPRINTS TYPES IN ALL THE PEOPLE OF BOTH CONTROL GROUP AND TEST GROUP.

\begin{tabular}{|c|c|c|c|c|c|c|}
\hline \multirow[t]{2}{*}{ Fingerprints type } & \multicolumn{2}{|c|}{ Test group } & \multicolumn{2}{|c|}{ Control group } & \multirow[b]{2}{*}{ X \& PV } & \multirow{2}{*}{$\begin{array}{l}\text { Odds ratio } \\
95 \% \text { CI }\end{array}$} \\
\hline & $\%$ & numbers & $\%$ & numbers & & \\
\hline Whorls & 50 & 197 & 36 & 122 & $X^{2}=10.83$ & $1.74^{*}$ \\
\hline Other types & 50 & 158 & 64 & 214 & $\mathrm{P}=0.001$ & $(1.025,2.42)$ \\
\hline Loops & 43 & 128 & 57 & 162 & $\mathrm{X}^{2}=12.32$ & $0.56^{*}$ \\
\hline Other types & 57 & 173 & 43 & 122 & $\mathrm{P}=0 / 0004$ & $(0.4,0.77)$ \\
\hline Arch & 15 & 46 & 18 & 52 & $X^{2}=0.65$ & 0.84 \\
\hline Other types & 85 & 255 & 82 & 82 & $\mathrm{P}=0 / 42$ & $(0.54,1.29$ \\
\hline
\end{tabular}

As the above result show, distribution of loop and whorls cases in control group and test group are heterogeneous and meaningful and odds- ratio also confirm it. But distribution of arch type is homogeneous and not meaningful.

\section{DISCUSSION}

The performed studies on dermatoglyphics in different disease have shown that they find especial forms in some diseases, especially in diseases which relate with chromosome abnormality. For example, in kline felter syndrome (the men with 47 chromosomes), a-b ridge is less than usual and the atd angel has been increased. In 1993, Baliger and Murthy performed a study. They examined, palms dermatoglyphics of some men and women, settled in north west of India, who had Schizophrenia background compared with those and their relatives who had not been affected with Schizophrenia. The results showed that some diseases had hereditary backgrounds.

In cases which had statistic as aspects, unusual conditions of dermatoglyphics in diabetics are valuable. So, it seems dermatoglyphics can be a noteworthy method for genetic studies and surveys related to the prevention of diabetes (type I).

Some of the most important dermatoglyphics characteristics of diabetic patients which have reported in recent years $(1,2,3,8)$ are: deduction of ridge count in the fingers II region and IV in diabetic patients, deduction of dermatoglyphics for middle finger and decrease of a-b ridge count, proportional deduction of line $\mathrm{c}$ in diabetic patients in 
regard to healthy people, the increase of atd angle and the growth of main width lines.

In comparison between Khorasan diabetic patients and English decreased, it seems that a-b ridge count in English diabetic men has been decreased rather than Khorasan diabetic men, but in English diabetic women have increase rather than Khorasan diabetic women (1, 2, and 5). In total comparison between diabetic patients and control group, it is observed that a-b ridge count in both diabetic men and women has been decreased rather than control group. A-b ridge count in both test group and control group has been lessened in women than men too. For atd angle measuring we can say, in comparison between Khorasan diabetic patients and English diabetics, it seems that atd angle size in diabetic women has increased rather than Khorasan diabetic men, but there is no change in atd angle size in English diabetic women and Khorasan diabetic women.(5)

In total comparison between diabetic patients and control group ,it is observed that atd angle in English diabetic men has increased rather than control group, but it has been decreased in Khorasan diabetic men rather than control group. The change may have been caused for racial different between control and diabetic patients in khorasan. Atd angle size in both test group and control group of women is more rather than men. As heredity is an essential element to cause diabetes disease, it is necessary to be performed more dermatoglyphics surveys over more people based on quantitative and qualitative characteristics of dermatoglyphics of diabetics. Perhaps, this survey can be used for warning the disease and division different type of diabetes based on dermatoglyphics characteristics. In general conclusion, it seems that dermatoglyphics knowledge as a warning for relation of diabetes with genetics, needs more studies. The performed researches have shown that one of the quantitative dermatoglyphics characteristics in of diabetic women is the increase of arch forms in fingertips rather than control group. These findings have also been observed in some surveys which have been done in Sardney region, Italia. In Khorasan, those findings were found in the patients affected with IDDM, too. The arch forms in test group were higher than control group $(2,4)$. In addition, in a-b ridge count, the rate of lines in diabetic patients had a significant decrease than control group. Of course, the decrease of arch forms and the increases of whorls in Schizophrenic have been observed too. Therefore, to determine the type of the disease exactly, it is necessary the other characteristics to be used, especially ridge count of fingertips. The result of derrmatoglyphics survey in Markazi State showed that there is no meaningful difference between Markazi diabetics and Khorasan diabetics from quantitative and qualitative points. The results also showed that there is the decrease of loops of fingertips in diabetic patients and the decrease of whorls of fingertips and the increase of arch in fingerprints of diabetic women. So, according to the above, more researches should be done about dermatoglyphics and diabetes.

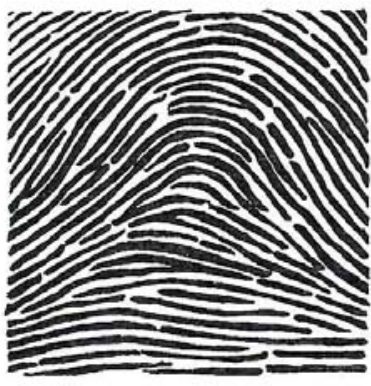

Plain Arch

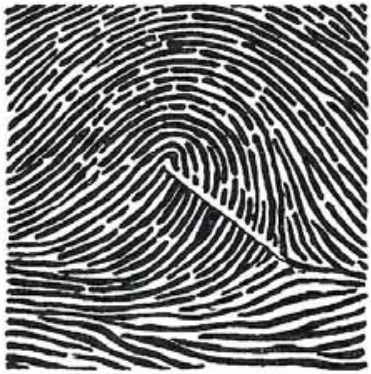

Loop

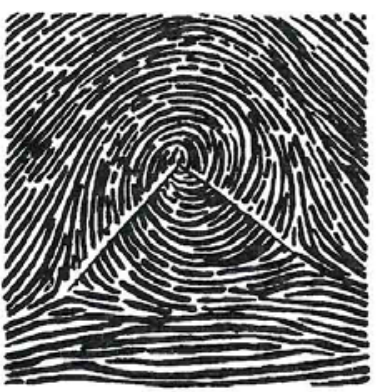

Outer Whorl

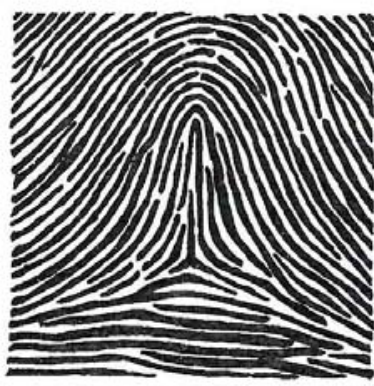

Tented Arch

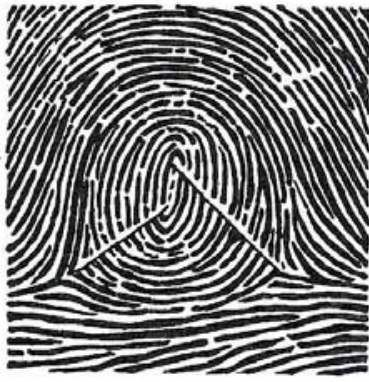

Meet Whorl

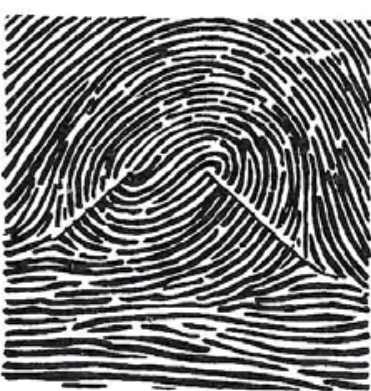

Whorl

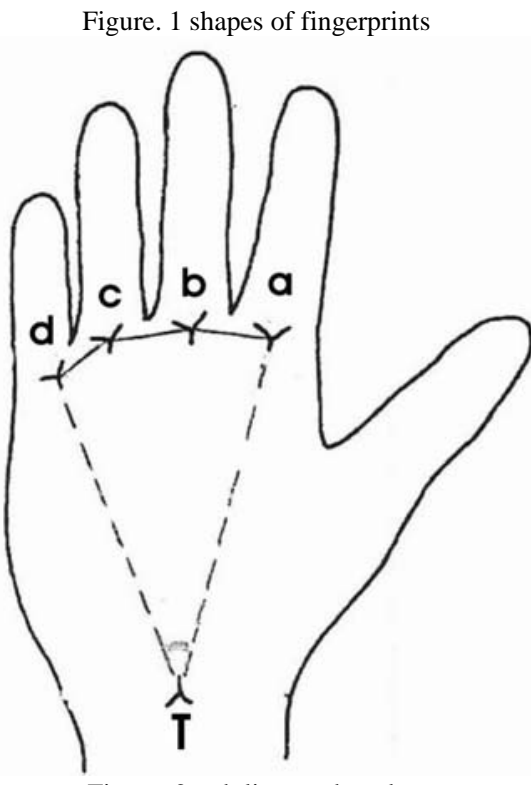

Figure. 2 a-b line, atd angle

\section{REFERENCES}

[1] Baca O.R. Oel valle , Mendoza L , Guerrero N.A. 2001, dermatoglyphics of a high altitude Peruvian population and interpopulation comparsions, High Alt . Med . Biol ,2(1): 31-40

[2] CVJaicanin M . Polovina A, 2000 , Quantitative analysis of digitopalmar dermatoglyphics in male children with central nervous system lesion by quantification of clinical parameters of locomotor disorder. Acta Med . Croatica , 53(1) : 5-10 
[3] Ponnudurai R . 1999, Relevance of sequential development of dermatoglyphics to schizophrenia , psychiatry Res. 89(1) : 59-67

[4] sivkov s. Akabaliev V. 1998 , Dermatoglyphics in schizophrenia : qualitative aspects , Folia Med , 40(3): 44-50

[5] Shamsuddini Sadullah , Muhammad Abadi H. 1981, Determining of alopecia and type of fingerprints , journal of skin diseases , 2(2): 22-22

[6] Mahdavi Shahri Nasser , 1994-95 , study of Qualitative dermatoglyphics in sardonian diabetics (Italy), Ferdowsi university publication , Mashhad , Iran

[7] Rezai F , Haddad F , Mahdavi Shahri N.1999 , a report of dermatoglyphics characteristics in a barbarian population resident in khorasan province and its application in physical anthropology , a collection of papers abtract , Iranian first congress on applied biology , 164, Mashhad, Iran

[8] Sharif kamali Mohammad, 1982 , collection of anthropologic papers , 17-43, Tehran , Iran 